\title{
ВЕРБАЛИЗАЦИЯ ИДЕОЛОГЕМ В ЛОЗУНГАХ ГДР
}

\section{VERBALIZATION OF IDEOLOGEMES IN THE POLITICAL SLOGANS OF THE GDR \\ E. Tumanova}

Summary: The article is devoted to analysis of the concept of «ideologeme», which is a key in the description of the language picture of the political world of German speakers, and the ways of its implementation in the slogans. Important role in building political slogans play a stylistic means of establishing an apt phrase. The author conducts the analysis of the stylistic figures used in the slogans of the GDR for transmitting ideologemes.

Keywords: political slogan, language of the GDR, ideologeme, persuasive effect, regulatory text.
Туманова Екатерина Олеговна

К.филол.н., доцент, Московский городской университет управления Правительства Москвы имени Ю.М. Лужкова, TumanovaEO1@edu.mos.ru

Аннотация: (татья посвящена анализу понятия «идиологема», которое является ключевым при описании языковой картины политического мира носителей немецкого языка, и способам его реализации в лозунгах ГДР. Важную роль в построении политических лозунгов играют стилистические средства создания метких фраз. Проводится анализ стилистических средств, используемых в лозунгах для передачи идеологем.

Ключевые слова: политический лозунг, язык ГДР, идеологема, персуазивный эффект, регулятивный текст.

Мифологемы приводят к канонизации реальных исторических событий, поэтизации героических поступков и преображению повседневности. Миф - это не только поучительная история, облаченная в красивую художественную форму, но и регламентация, санкционирование определенных поведенческих моделей в социуме. Именно поэтому мифологемы сегодня бытуют во многих сферах общественной жизни - в культуре, политике, массовой коммуникации, рекламе, т.е. мифологемы продолжают свое существование в определенном социальном пространстве. Поэтому мы можем говорить о контекстных измерениях мифологем - культурном, идеологическом и мультимедийном [1].

В идеологическом контексте мифологема может выступать в качестве собственно культурного феномена (как прецедентное имя и прецедентное событие), и как идеологема [2]. Мифологема может быть рассмотрена как некий прототип идеологемы. По своей сути и мифологемы, и идеологемы одинаковы, т.е. сложные явления облекаются в устойчивую словесную формулу и благодаря ей редуцируются до «общепонятных идей» (Э. Дюркгейм). Очевидным преимуществом таких явлений становится максимально быстрое и легкое внедрение в массовое сознание, что позволяет им превращаться в стереотипные номинации, воспринимаемые как «предмет веры, а не рассуждения» (Л. Леви-Брюль). Оба явления обладают суггестивностью, так как нацелены на эмоциональное воздействие.

Отличительной особенностью мифа является сохранение в себе исторического опыта человечества в то время, как идеологема ориентирована на будущее, являясь инструментов борьбы за власть. 
Таким образом, мифологемой, используемой в идеологических целях, следует называть идеологему [1]. Подобно предкам, которые благодаря мифологемам могли познавать окружающий мир, современные люди используют идеологемы для структурирования и объяснения окружающей их политической действительности и вырабатывать собственную картину политического мира в соответствие с принятой в социуме идеологией. Представляя собой сложный когнитивно-стилистический феномен, идеологема участвует в формировании массового, коллективного и индивидуального сознания конкретного народа.

Идеологемы играют непосредственную роль в идеологическом кодировании современной действительности с целью формирования социальной идентичности. Стоит отметить, что процесс идеологического кодирования является комплексным и многогранным, в котором на первом месте выступают эмоциональность, прагматичность и легкость запоминания смыслового содержания, нежели чем его простая оценка.

Реализации идеологемы предшествует ее замысел, так как в основе каждой идеологемы лежит заранее сформулированная идея, которая позволяет задать нужную ориентацию для массового сознания [3]. Отметим, что встраивание в массовое сознание идеологического кванта смысла как главная функция идеологемы реализуется на когнитивном уровне, но благодаря лингвистическим средствам.

Исследование идеологии с лингвистической точки зрения не является новой задачей, однако, в нашей работе мы хотим провести анализ языковых средств, позволявшим создать определенную идеологическую направленность высказываний.

В обществе существовало всегда множество средств выражения политических идей. Одним из средств идеологического влияния в эпоху ГДР, облаченного в яркую языковую форму, являются лозунги, которые писались на транспарантах и вывесках по случаю государственных праздников и демонстраций. Наиболее яркие изречения служили поводом для трансформации с целью создания комического эффекта и выражения иронии.

Как средство политической борьбы и пропаганды различных социальных групп и политических движений, как средство привлечения внимания и манипулирования сознанием лозунги известны уже давно, так как им свойственна реализация целого ряда прагматических характеристик: суггестивности, персуазивности, директивности, оценочности, особого проявления категории адресованности. Особо стоит отметить директивную, или предписывающую, характерную черту лозунга как средство формирования политической картины мира в сознании индивидов. Именно наличие этой черты позволяет рассматривать лозунги как разновидность регулятивных текстов, т.е. своеобразных предписывающих инструкций для адресатов по поводу приемлемости тех или иных действий по отношению к окружающей реальности. Таким образом, перед нами предстает двойственная природа лозунга. С одной стороны, мы говорим об языковой вербализации общественной мысли и общественных настроений, с другой стороны, политический лозунг может стать эффективным орудием в борьбе за политическую власть и манипулирование сознанием народных масс.

В нашем исследовании под лозунгом понимается обращение, в лаконичной форме выражающее руководящую политическую идею, требование, которое размещено на щите или полотне, или любом другом носителе [4].

Политически лозунг - это особый жанр политического дискурса и непосредственный инструмент политической борьбы, который занимает центральное место в политической коммуникации. В качестве объекта лингвистического анализа ключевыми характеристиками лозунга являются ясность и выразительность, предельная сжатость и целенаправленное воздействие на политическую картину мира реципиентов сообщения.

Основной функцией лозунга принято считать стремление изменить мнение адресата в пользу адресанта, что лишает лозунг какой-либо объективности. Под «политическим лозунгом» следует понимать оценочное высказывание, оказывающее особое эмоциональное воздействие на реципиента и способствующее формированию плодотворной основы для поддержания новых идеологических установок. Усилению эмотивной и персуазивной функций лозунгов способствуют разнообразные лингвостилистические средства, отражающие всю совокупность прагматических особенностей лозунговых выражений. Немецкий язык обладает целой палитрой средств для создания персуазивного эффекта, однако построение лозунгов чаще всего происходит по определенным языковым моделям.

Объектом настоящего анализа стали 206 лозунгов ГДР. Предметом - языковые особенности отражения в них исторической эпохи. Лингвистическая характеристика лозунгов представлена на синтаксическом уровне языка.

Яркая и образная речевая формула лозунга способствует его быстрому и легкому запоминанию, а также притягивает внимание реципиентов. В создании лозунгов в этой связи одно из центральных мест принадлежит лексическим средствам, создающим персуазивный эффект. Учитывая общеизвестный факт, что усилению экспрессии высказываний служат стилисти- 
ческие средства, их анализу употребления в лозунгах мы посвятили отдельную часть исследования. Данный анализ позволят нам показать, какими ресурсами и возможностями воздействия на народные массы обладают лингвистические средства вербализации идеологем в политических лозунгах. Бесспорно, что ключевая прагматическая характеристика политического лозунга - персуазивность, поэтому стилистические особенности непосредственно связаны с реализацией персуазивного эффекта, тем самым формированием идеологем в политической картине мира реципиентов. В целом ряде политических лозунгов содержатся языковые и политические реалии и множество аллюзий, понятным только носителям конкретного языка, обладающим определенными фоновыми знаниями по истории, политике, религии и культуре, т.е. людям со сформированной языковой картиной политического мира. Связь лозунгов с особенностями национального менталитета и мышления народа объясняется их прагматическими свойствами. Другими словами, лозунг носит индивидуальный характер, и хранящаяся в нем идеологема может быть расшифрована только носителями конкретного языка. Каждый лозунг уникален по своей природе. В этой связи, стилистические средства, используемые при создании лозунгов, представляют собой особые авторские языковые решения, облеченные в легко запоминающуюся речевую формулу. Удачный лозунг - это особый вид речевого искусства, который в дальнейшем может стать частью фонда крылатых единиц конкретного языка.

Исследование стилистических фигур в составе лозунгов позволяет оценить степень важности их использования. Тропеические и диаграмматические фигуры применяются для придания высказыванию яркости и изобразительности. Стоит отметить, что чаще всего эти фигуры функционируют не по одиночке, а совместно с другими фигурами, что придает высказыванию большую экспрессию.

Среди наиболее частотных тропеических фигур мы можем выделить метафору, метонимию, сравнение, антитезу.

Метафора способствует наглядной передаче связных представлений и одновременно предельно экономичному представлению мысли, например, „Der Sozialismus ist für alle da, er braucht alle und hat für alle Platz".

Метонимия служит для создания детализированной картины, представляющей привлекший внимание автора элемент действительности крупным планом или обнажающей логические взаимосвязи: «процесс - субъект процесса», «признак - носитель признака», «процесс результат процесса»: „Wer Qualität kaufen will, muss Qualität produzieren!", „Aus Stahl wird Brot!"

Реализации антитезы в лозунге чаще всего проходит на лексическом уровне, за счет узуальных антонимов, например, „Vorwärts immer, rückwärts nimmer!“ или окказионального противопоставления: „Frieden schaffen gegen NATO-Waffen" (Erich Honecker). Существуют случаи использования двух видов антонимов: „Wie wir heute arbeiten, werden wir morgen leben".

Диаграмматические фигуры представлены фигурами прибавления и фигурами размещения и перестановки. К фигурам прибавления в составе немецких афоризмов относятся эпимона, анафора, эпифора, анадиплозис, удвоение, геминации, гомеология, плеоназм и градация. Под фигурами размещения и перестановки понимаются синтаксический параллелизм, инверсия. Приведем некоторые примеры: „Mach mit mach's nach - mach's besser!" (анафора), "Arbeitszeit ist Leistungszeit!" (эпимона), "Was wollen wir: Frieden. Frieden." (геминация), "Von der Sowjetunion Iernen, heißt siegen lernen!" (эnифора), "Sozialistisch arbeiten, lernen und leben." (плеоназм).

Таким образом, познать историческую эпоху можно посредством лингвистического анализа текстов данного периода, в том числе и лозунгов, которые в период существования ГДР являлись средством воздействия на население, формирования социалистических идеалов и ценностей, а также идеологии в целом. Очевидным является стремление к обобщению и единению по средствам лексем wir, alle, jeder; борьбе за мир kämpfen, Frieden. Усиливающее действие лозунгов возникает за счет таких стилистических фигур как плеоназм, повторы (анаформа, эпифора, гомеология, гемминация, удвоение, плеоназм), стилистический параллелизм. Метафора и метонимия встречаются реже, так как задача руководства ГДР была сформировать конкретные представления и дать народу соответствующую установку, исключив возможности ее неоднозначного истолкования.

Настоящая работа послужила подтверждением роли германистики в изучении истории, политической риторики и отчасти особенностей речевого воздействия и манипуляций массовым сознанием.

\section{ЛИТЕРАТУРА}

1. Клушина Н.И. Контекстные измерения мифологемы / Н.И. Клушина // Стилистика сегодня и завтра : материалы конф. М., 2014. С. $154-157$. 
2. Нахимова Е.А. Идеологема «Сталин» в современной массовой коммуникации / Е.А. Нахимова // Политическая лингвистика. 2011. № 2. С. 152-156.

3. Клушина Н.И. Семантические и стилистические изменения в лексике современной газеты (на материале газет 1989-1994 гг.) / Н.И. Клушина/ : дис. ... канд. филол. наук. М., 1995. - 200 с.

4. Туманова Е.0. Афоризм во фразеологии и фразеологизм в афористике современного немецкого языка (лингвокультурологический аспект) / Е.0. Туманова/: дис. ... канд. филол. наук. М., 2012. - 293 с.

(c) Туманова Екатерина Олеговна (TumanovaEO1@edu.mos.ru).

Журнал «Современная наука: актуальные проблемы теории и практики»

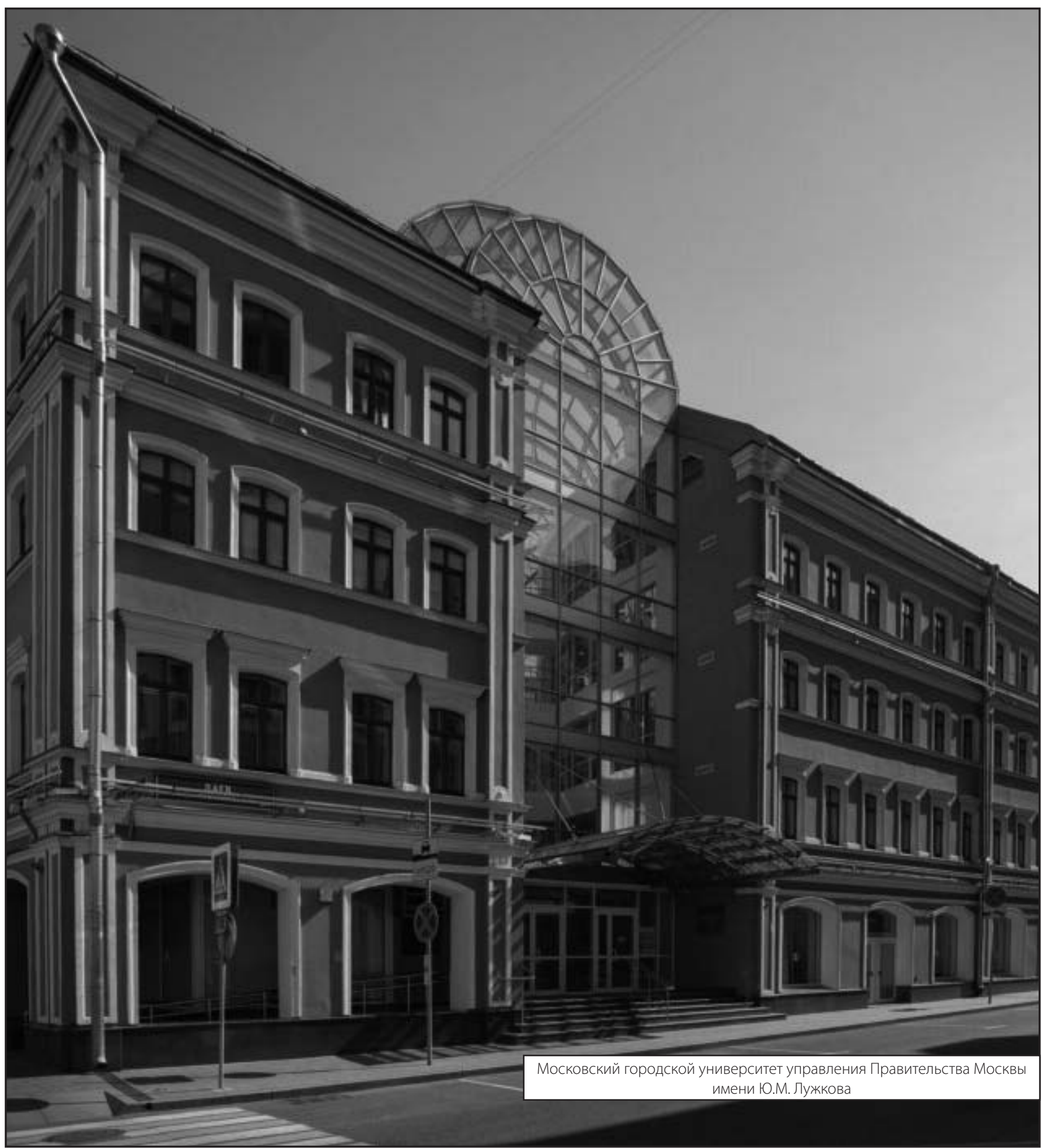

